University of Wollongong

Research Online

Faculty of Business - Papers (Archive)

Faculty of Business and Law

$1-1-2019$

Accounting and pastoral power in Australian disability welfare reform

Mona Nikidehaghani

University of Wollongong, monan@uow.edu.au

Corinne L. Cortese

University of Wollongong, corinne@uow.edu.au

Freda C. Hui

University of Wollongong, fredah@uow.edu.au

Follow this and additional works at: https://ro.uow.edu.au/buspapers

Part of the Business Commons

Research Online is the open access institutional repository for the University of Wollongong. For further information contact the UOW Library: research-pubs@uow.edu.au 


\title{
Accounting and pastoral power in Australian disability welfare reform
}

\author{
Abstract \\ This paper draws on Foucault's concept of pastoral power to explore the role of accounting in the \\ Australian disability welfare reform. We provide an example of the use of individualising and totalising \\ power against a backdrop of neoliberal reform. Our analysis reveals the centrality of accounting practices \\ in transforming the identity of people with disabilities into one consistent with the intentions of \\ neoliberalism ideology. Our findings demonstrate that accounting practices associated with disability \\ welfare reform have been integral in exercising pastoral power. We further demonstrate that accounting, \\ as a technology of the self, facilitates individualising and totalising control and, through a perpetual \\ extraction of truth, constructs an individual's conduct. \\ Disciplines \\ Business \\ Publication Details \\ Nikidehaghani, M., Cortese, C. \& Hui-Truscott, F. (2019). Accounting and pastoral power in Australian \\ disability welfare reform. Critical Perspectives on Accounting, Online First 1-15.
}




\title{
Accounting and pastoral power in Australian disability welfare reform
}

\begin{abstract}
This paper draws on Foucault's concept of pastoral power to explore the role of accounting in the Australian disability welfare reform. We provide an example of the use of individualising and totalising power against a backdrop of neoliberal reform. Our analysis reveals the centrality of accounting practices in transforming the identity of people with disabilities into one consistent with the intentions of neoliberalism ideology. Our findings demonstrate that accounting practices associated with disability welfare reform have been integral in exercising pastoral power. We further demonstrate that accounting, as a technology of the self, facilitates individualising and totalising control and, through a perpetual extraction of truth, constructs an individual's conduct.
\end{abstract}

\section{Introduction}

In 2005, Australia’s Prime Minister John Howard ${ }^{1}$ (1996-2007) instigated major reform across most realms of social life in an attempt to secure the status of neoliberal orthodox in Australia (Maddison \& Martin, 2010). Affected groups included refugees, indigenous Australians, unemployed people, and people with disabilities. Howard's disability welfare reform program, which continues to affect people with disabilities, was driven by "workfare"2,

\footnotetext{
${ }^{1}$ Prime Minister John Howard was the leader of the Australian Liberal Party, which was in government in Australia from 1996 to 2007. The Liberal Party is one of the major political parties in Australia.

${ }^{2}$ The concept of workfare was first discussed by US President Ronald Reagan. It became fully effective in the US during the presidency of Bill Clinton with the Personal Responsibility and Work Opportunity Reconciliation Act 1996 (Abramovitz, 2006). Currently, with most global policy institutions such as the OECD and IMF promoting workfare (Humpage, 2007), it is practiced internationally (Haylett, 2003). Since the beginning of the 21st century, most western nations have embarked on restructuring welfare programs to comply with the requirements of a workfare state (Goodin, 2002; Peck, 2001).
} 
and was based on a central national social plan of neoliberal global reform (Soldatic, 2009). Based on a neoliberal policy of "no rights without responsibilities” (Fiske \& Briskman, 2007, p.50), workfare shifted emphasis from citizens' "entitlements" to their "obligations" (Macintyre, 1999, p.103). Prime Minister Julia Gillard's ${ }^{3}$ introduction of the Australian National Disability Insurance Scheme (NDIS) in 2013 has arguably furthered the move towards a neoliberal disability welfare model (Thill, 2015). People with disabilities are now viewed as consumers participating in a market-based model of disability service provision (Malbon, Carey, \& Dickinson, 2018). Like the Howard government's disability welfare reforms that are the focus of this paper, NDIS rhetoric claims to give people with disabilities the capacity for “self-determination”, “independence”, and “choice and control” (The Department of Families Housing Community Services and Indigenous Affairs, 2013).

The objective of this study is to explore how accounting techniques were used as part of Australian disability welfare reform to transform people with disabilities into "effective citizens”. We use Foucault's (2007) notion of pastoral power to reveal the presence of accounting practices that were embedded within the disability welfare reform program. We argue that the centrality of accounting in transitions of identity align closely to neoliberal administrative and bureaucratic processes. We connect the Howard government’s disability welfare reform scheme to the contemporary disability welfare practices and argue that the current disability welfare programs are underpinned by these neoliberal mentalities, and that accounting technologies and rationales are applied as a biopolitical apparatus for the reconstruction of people with disabilities in Australia. In doing so, we demonstrate how the

\footnotetext{
${ }^{3}$ Prime Minister Julia Gillard was the leader of the Australian Labor Party, which was in government from 2007 to 2013. Gillard held the position of Prime Minister from 2010 to 2013. The Labor Party is a major political party in Australia.
} 
techniques, rationales, and technologies of accounting enable an exercise of power that is individualising and totalising (Foucault, 2007, p.128).

As rendering individuals "economically accountable" is a significant component of the current globalised world (Arrington \& Upton, 2013), research into the force of accounting in this political context is relevant. Modern states pay great attention to individual identities, and they do so within sophisticated structures that shape citizens' identities in new forms compatible with predictable and malleable patterns (Miller \& Rose, 1990; Radcliffe, 1998). Like other expert practices and the discourses that accompany them, accounting techniques are integral to fulfilling the objectives of the modern state (Andrew, 2007; Walker \& Carnegie, 2007; Zhang, Andrew, \& Rudkin, 2012). Accordingly, this paper contributes to the existing literature on accounting and biopolitics (Cooper, Graham, \& Himick, 2016; Martinez, 2011; Walker, 2008) by demonstrating the role of accounting in the transformation of people with disabilities into an identity consistent with the “economism” (Brohman, 1995, p.297) inherent in neoliberalism.

The contribution of this study to the literature is twofold. First, it aims to expand Focualdian accounting research by implementing Foucault's notion of pastoral power, which is a relatively under-researched aspect of Foucault's work (Graham, 2010). Although various aspects of Foucault's work have informed accounting scholars (Chiapello \& Baker, 2011; Napier, 2006), Foucault's thesis on disciplinary power and governmentality has so far attracted the most attention from accounting scholars (McKinlay \& Pezet, 2010). However, recent accounting literature suggests that by focusing on Foucault's study of the methods and practices by which individuals transform their own mode of being (Foucault, 1988), we can enhance understanding of accounting as a technique of the self (Kosmala \& McKernan, 2011). Our study contributes 
to this body of research by analysing the role of accounting in the transformation of people with disabilities through the lens of Foucault's notion of pastoral power.

Second, despite numerous Foucauldian studies that examine how accounting facilitates political agendas across a range of identities (e.g. Bujaki, Gaudet, \& Iuliano, 2017; Graham, 2010; Greer \& McNicholas, 2017; Jeacle, 2003; Miller \& O'Leary, 1987; Neu \& Graham, 2006), there is limited research that interfaces accounting with social policies targeted at people with disabilities. In fact, disability researchers Colin Barnes and Geoff Mercer (2005, p.539) have argued that "few social theorists have pursued their analyses [of disability benefits and services] in ways that enlighten the circumstances of experiences of disabled people”. In response, our research reveals the implications of accounting for disability welfare reform in Australia from 2005 when the reform was initiated by the Howard government to the present day. In doing so, we question the assumptions underlying the Disability Support Pension (DSP) and critique the Howard government's neoliberal intentions and how they continue to find expression in the administrative procedures necessary for people with disabilities to receive economic resources.

The remainder of this paper first discusses the application of a Foucauldian approach in the accounting discipline. Next, the concept of pastoral power is described, along with the source of the evidence obtained for the use of pastoral power as a lens to explain the disability welfare reform. We use this to demonstrate accounting as a technology of the self that reinforces attempts to transform people with disabilities into an effective entity. Finally, we offer some concluding comments and opportunities for future work.

\section{Foucault, pastoral power, and accounting}

Since the late 1970s, accounting scholars such as Hopwood $(1978,1983)$ and Burchell et al. (1980) have challenged the conceptualisation of accounting as a neutral technique (Napier, 
2006) that provides accurate information for improving economic efficiency (Watts \& Zimmerman, 1986). Accounting has been seen as an extremely powerful discursive practice that constructs, rather than simply reports upon, social realities (Burchell, Clubb, \& Hopwood, 1985; Loft, 1986, 1988; Miller \& O'Leary, 1987). Works by Michel Foucault have had a significant influence on the accounting literature, which views accounting as a socially constructed practice (Bigoni \& Funnell, 2015; Chiapello \& Baker, 2011; McKinlay, Carter, Pezet, \& Clegg, 2010; Napier, 2006).

The Foucauldian perspective has influenced accounting researchers to consider the discipline in a manner that captures the breadth and scope of accounting's influence on organisations and modes of administration that historically have not focused on financial issues (Carnegie, 2014; McKinlay \& Pezet, 2010; Napier, 2006). For example, accounting scholars such as Hoskin and Macve (1986, 1988, 1994), Fuinez (2005), Loft (1986, 1988), Miller and O'Leary (1987), Vollmer (2003), and Walker (2010) have applied Foucault's notion of disciplinary power in conceptualising accounting as a cultural presence through which forceful modes of power operate. Accounting has been understood as a powerful disciplinary mechanism that makes people knowable and calculable. As such, accounting is perceived as a ubiquitous "technology of power" that facilitates the creation of "docile bodies" (Carmona, Ezzamel, \& Gutierrez, 2002; Carmona \& Gutiérrez, 2005; Knights \& Collinson, 1987).

Foucault's (1991) concept of governmentality has also enabled accounting scholars to demonstrate both the "reflective" and "constitutive" (Napier, 2006, p.455) aspects of accounting. Foucault's (1991) notion of governmentality refers to the "ensemble of institutions, procedures, analyses and reflections, the calculations and tactics” (p.102) that are used to arrange things so that desired ends are achieved. According to Foucault (1991), governmentality emerged in the 18th century, when the predominant concern of government 
was the improvement of the population's conditions, welfare, and wealth (Foucault, 1991). The population was not merely an assemblage of individuals; rather, it had its own life and purpose that had to be meticulously managed (Foucault, 1991). Accordingly, Foucault (2003) used the term "governmentality" to refer to a "group of relations of power and techniques that enables exercising the relations of power” (p. 135).

Accounting scholars have applied Foucault's concept of governmentality to explain how accounting is central to power in both the modern state and the modern corporation (Miller \& Rose, 1990; Sargiacomo, 2009). Accounting numbers, due to their “mobile, stable and combinable" characteristics (Robson, 1992, p.685, emphasis in original) are capable of expediting "government at a distance” (Miller \& Rose, 1990, p.9). From a governmentality perspective, accounting is researched at a level of particularity, where it is construed as an “instrument of power and domination” (Carnegie \& Napier, 1996, p.8). Using Foucault’s governmentality, scholars have analysed how accounting penetrates most aspects of social life as it facilitates the governing of a range of domains, including the relations between the population and the state (Baños, Gutierrez-Hidalgo, Alvarez-Dardet, \& Carrasco, 2005; Neu, 2000a), as well as relations within firms and organisations (Dean, 1999; McKinlay \& Taylor, 2014).

Foucault (1982) claimed that governmentality is a new form of an old power technique known as pastoral power, which originated with the Christian church (Foucault, 2007). Through its clergy and religious orders, the Christian church exercised power over its members in an attempt to control them and direct them towards salvation (Foucault, 2007). Foucault's (2007) interpretation of Christian pastoral power has features of the Hebraic shepherd-flock relation, which sees power as exercised over a moving flock, rather than over a particular territory. The shepherd guides the flock towards an end, and the aim of exercising power is the 
salvation of the flock. Foucault (2007) notes that pastoral power manifests as a benevolent power insofar as pastors must care for the members of their church and be ready to sacrifice themselves if necessary. It is both individualising and totalising: pastors must care for the entire population as a whole, as well as each member individually (i.e. the principle of omnes et singulatim) (Foucault, 2007, p.124-129).

According to Foucault (1991, 2003), the governmentalised state functions in the same manner: the state considers the interests of each individual within the population while simultaneously pursuing the objectives of the entire population. Foucault (2001) notes that this individualising and totalising principle, originating in Christian pastoral power (Foucault, 2007), has characterised the modern state. In this sense, Foucault (1982, p.215) argues that "we can see the state as a modern matrix of individualization... a new form of pastoral power”.

Foucault (1982) notes that although the ecclesiastical aspect of Christian pastoral power has diminished since the 18th century, its function has spread and multiplied outside the ecclesiastical institution. Foucault (1982) suggests that in its modern form, the objective of pastoral power has shifted from achieving salvation in the next world to securing it in this world, and is exercised through a bureaucratic system that aims to achieve "salvation" in the form of health, economic welfare, and security. The pastor's primary task in directing the population toward salvation is to teach the truth. Foucault (2007) asserts that teaching the truth is individualised and interwoven with power. This teaching is a direction of daily conduct that is exercised through uninterrupted observation of the actions of each individual; this observation is to "form a never-ending knowledge of the conduct of the individuals" (Foucault, 2007, p.181). In teaching the truth, the pastor must direct the souls and conscience of the individuals, which Foucault (2007, p.181) addresses as "spiritual direction”. This direction is not voluntary; rather, it is obligatory and absolutely permanent; "one is directed with regards 
to everything and for the whole of his life” (Foucault, 2007, p.182). Spiritual direction and teaching the truth are practiced by means of self-disclosure (confession). A Catholic Christian pastor obliges individuals to confess their inner thoughts, temptations, and desires so the pastor can comprehend their consciences and direct their souls (Foucault, 2007). The function of verbal confession is to reinforce the subordination of the individual to the pastor. Confession provides a tool for the pastor to extract the truth from individuals, and thus direct their conduct. Hence, confession reinforces the exercise of pastoral power (Foucault, 2007).

Foucault's (1988a, 1988c, 2000) analysis in the History of Sexuality illustrates that in contemporary modern life, the human sciences have reinserted the techniques of verbal confession developed by Christianity, such as writing, diarising, and reflecting on one's actions, in a different context. Human science applies these techniques to "constitute, positively, a new self” (Foucault, 1988c, p.49). Foucault's (1988a) remarks that the social sciences, especially those in "psy" disciplines, demand individuals' verbal or written confessions in order to access their inner thoughts and assess the purity of those thoughts; this is part of knowing individuals' true identity. However, the necessity of an expert to interpret the confession demonstrates that in the modern world, confession remains an instrument of subordination (Foucault, 1988a).

The pastoral aspect of the modern state has encouraged researchers to consider pastoral governance in different domains of intervention that seek to modify the conduct of individuals; these include, for example, education (Ideland \& Malmberg, 2015), public policies (Gustafsson \& Driver, 2005), and mental-health policies (Helsel, 2015). Scholars such as Bigoni and Funnell (2015), Greer and McNicholas (2017), and Neu et al. (2015) stress the importance of considering Foucault's notion of pastoral power in studies of accounting. In particular, Bigoni and Funnell (2015) emphasise that, with the ever-increasing governmentalisation of the modern 
state, implementing Foucault's thoughts on pastoral power could advance the conceptualisation of accounting from a technology of power to a technique of the self. Accordingly, by considering the assimilation of pastoral power into the modern state, our study explores Australian disability welfare reform as a manifestation of pastoral governance and explains how accounting facilitates modes of subjectification for people with disabilities.

\section{Method}

This study is part of a broader project that undertook a genealogical approach to examine the role of accounting in transforming the identity of people with disabilities under the Australian Disability Welfare Scheme since 1908 (for other genealogical approaches in critical historical accounting research see Edgley, 2014; Everett, Green, \& Neu, 2005; Himick, 2011; Macintosh, 2009; Miller \& O'Leary, 1987; Yayla, 2011). These types of investigations involve thorough reviews of the archives of documents oriented toward the role of accounting in forming identities, and in enacting policy over those identities (Graham, 2010; Greer \& McNicholas, 2017; Neu \& Graham, 2006). While we acknowledge that other research techniques, such as interviews with lawmakers and people with disabilities, are of value in obtaining empirical evidence, particularly in studies with a more recent temporal focus such as this one, we have chosen to recognise our reliance on secondary sources as a limitation given that our data collection was contextualised within this broader project. For this particular study, our objective is to examine how accounting techniques can be used as a transformative device. We argue that this is achieved by the imposition of accounting classifications on people with disabilities and the requirement that people with disabilities make written "confessions" regarding their individual circumstances. In relying on secondary data to advance our arguments, we do take on board Fleischman and Tyson’s (2003, p.43) admonitions that archival researchers must "describe the archive, its locations and contents, and the theoretical 
framework of the work". Having described our theoretical framing, we now describe the archive and its scope.

To determine how accounting came to be embedded within the disability welfare scheme, it was important to review parliamentary and legislative data. Data was also needed from Australian government websites to ascertain how accounting techniques have been used to gather information about individuals participating in the welfare program. To obtain this information, we relied on digitally archived files and documents.

Archival data was collected manually from publically available sources, including the Australian Parliament website, the Federal Register of Legislation website, Australian government websites, and the Australian Government Web Archive (AGWA). Data obtained from the Australian Parliament website includes the Parliamentary Hansards, Bills Digests, papers, and transcripts of speeches and interviews by Howard's Ministry discussing disability welfare reform. Data accessed through the Federal Register of Legislation website includes Employment and Workplace Relations Legislation Amendment (Welfare to Work and Other Measures) Act (2005). Data retrieved from publicly available Australian government website and the AGWA consists of Guides to Social Security Law from 2006, which includes guidelines for the Job Capacity Assessment from 2006, Claim Verification from 2006, Claim Lodgement from 2006, Qualification for disability support pension from 2006, Participation Requirements for DSP Recipients from 2014, and Active participation in a program of support (DSP) (Australian Government, 2016). Data obtained from the Australian government website and the AGWA also comprised application forms for DSP from 2006, income and asset report forms from 2006, the earning worksheet (Australian Government, Department of Human Services, 2014a), the account statement form (Australian Government, \& Centrelink, 2008), information on identification of assets and income for the purpose of DSP (Australian 
Government, 2016), official forms to report changes of circumstances (Australian Government, 2016b), and official forms for employment reports (Australian Government, 2016d). Evidence for this study also includes Ministerial interviews with national television networks.

All data was reviewed to determine the significance and relevance of each data subset. After an initial review, data was classified into two groups. The first data set, which was examined to understand the government's perspective towards disability welfare reform and the role of accounting in rationalising its perspective, included Parliamentary Hansards, Ministerial speeches and interviews, Bills Digests, and legislation. The second data set included official forms, such as application forms for the DSP and official guidelines designed to administer the legislation; this data revealed the importance of accounting in identifying people with disabilities and inducing an identity consistent with the neoliberal assumption of citizenship. For example, many of the application forms forced people with disabilities to engage with accounting techniques to acknowledge their circumstances. Examining these guidelines enabled us to understand the centrality of accounting to applicants, as well as to their ongoing compliance with the scheme once a participant.

\section{The Howard welfare reform}

A number of neoliberal reform packages that the Howard government undertook during the early 2000s were built on the notion of "mutual obligation", which demanded that those who were guaranteed a safety net do something in return (Commonwealth of Australia. House of Representatives, 10 Feb 1997, p.475). Maximising the participation of people with disabilities in the workforce continued to be a key issue. Senator Newman (1999), the then-Minister for Family and Community Services, commented:

A major challenge is the large and growing number of people on Disability Support Pension. Ten years ago, the equivalent numbers were around 300,000. Today, there are close to 600,000 people or about 6 per cent of the working age population on the disability pension. Unless we do something, it is likely that by 2006 , there will be over 750,000 people on the 
payment, possibly more than the number on unemployment payments. Many people with a significant capacity to work, needlessly stay on disability payments for a long time (Newman, 1999).

As a result, the Howard government sought fundamental changes to the Disability Support Pension (DSP) to align it with the mutual-obligation approach (Department of Family and Community Services, 2000). Since people with disabilities were one of the most marginalised groups of citizens, the Howard's Ministry had to moralise its disability welfare policies:

The Government does not view welfare reform as a cost cutting exercise; rather, as a structural change designed to reduce welfare dependency through greater economic and social participation. Full implementation of reform will require a substantial upfront investment of budget funds. Unless we make this investment, significant sections of the population may be excluded from the benefit of economic and social participation (Department of Family and Community Services, 2000, p.4).

This statement illustrates the manner in which accounting discourse helped the Australian Government to rationalise its disability welfare reform. The Howard government drew on the accounting discourse of cost and investment to present itself as a compassionate pastor willing to sacrifice extensive fiscal investment for the good of the nation. However, as Newman (1999) asserts, the good of the nation was couched in terms of economic participation. Simultaneously, to advance the agenda of transferring people with disabilities into the workforce, the Howard Ministry initiated a move to reframe common perceptions of people with disabilities. This reconceptualisation of people with disabilities was significant in gaining public approval for the disability welfare program, and the subsequent transformation of people with disabilities. The Howard government drew on the accounting discourse of taxation to classify people with disabilities as system abusers who took advantage of taxpayers' contributions. For instance, Newman, in a television interview about disability welfare reform, stated:

One way of that street is the battlers, ..., the people who are paying for this.

This is not Government money, this is taxpayers' money and many are not rich or doing better than the people on welfare, but they're still paying tax.

Now that's part of why it's a two-way street, one to give and the other to receive (Newman, 7.30 Report, 8 Nov 2000). 
Drawing on the concept of individual income tax, Newman divided the nation into two categories. One was ordinary citizens, the "battlers" who were experiencing financial difficulties but were mindful of their civic responsibility to pay tax. On the other end of the spectrum were the irresponsible disability welfare recipients who took advantage of the hard work of the battlers. It was through this classification of citizens into taxpayers and DSP recipients that the government planted the seeds of doubt regarding disability welfare recipients' authenticity in taxpayers' minds. This reframing encouraged public resentment, as it represented some as undeserving of disability support. Implied within Newman's statement was the prioritising of the working class over welfare recipients. The working class was framed as that which participated in the national economy through the payment of taxes. Hence, the state became accountable toward them, not toward the undeserving disability welfare recipients.

The concept of the "ability to generate income” enabled the Howard government to further categorise people with disabilities. When addressing the Howard government's intention to restructure the welfare system, Newman stated:

\footnotetext{
Of course, people with severe disabilities will always receive [the] Disability Support Pension. That's part of our safety net guarantee. But we also need to recognise that for some people at least, access to the disability pension is seen as a better alternative to unemployment benefits and the activity test that goes with it. At the same time, there are many people on disability pension who want to join the workforce or become more involved in community life, to their full capacity (Newman, 1999).
}

The technique of classifying people with disabilities based on their workability reinforced the individualising and totalising aspects of the reform: it would provide salvation in the form of welfare for people who were severely disabled. This group truly deserved the DSP, as there was no hope for them to improve their ability to generate income. Simultaneously, identifying the most deserving DSP recipient would enable the government to adequately allocate financial resources and fulfil its accountability towards the taxpayers. However, Newman's statement 
also identified another class of disability welfare recipients: the corrupt ones; those who could potentially harm the whole system. Such people could earn income; however, they were benefiting from DSP and costing taxpayers. The government, appearing as a caring pastor, took actions to prevent this undeserving group from "infecting" the rest of the population. At the same time, as part of the project of changing perceptions towards people with disabilities, the corrupted ones were situated close to the willing people with disabilities. These willing people represented the successful implementation of the disability welfare reform, in that they achieved salvation by being able to generate income through active participation in the workforce. This representation of some people with disabilities as undeserving of assistance, and as system abusers, facilitated the restructuring of the disability welfare system into a program closer to neoliberalist ideologies.

In implementing the disability welfare reform the Howard government relied on the authority of Commonwealth legislation: specifically, the Employment and Workplace Relations Legislation Amendment (Welfare to Work and Other Measures) Act (2005) (hereafter Welfare to Work Act). The Act, which was in line with the Howard government's neoliberalist perspective, was issued to "mould the behaviour" (Baños et al., 2005, p.207) of people with disabilities. As apparent in the Act's title, this transformation would happen by improving the employment prospects of people with disabilities. In practice, this legislation expressed the individualising and totalising principle of pastoral power: it would increase the effectiveness of the person with disabilities, thus providing extensive fiscal savings for the government (Department of the Parliamentary Library, 2005). In fact, the fiscal savings achieved by the legislation were the prime motive for this transformation:

This bill seeks to ... alter the eligibility for people to receive disability support pensions. This is an important point: this really is a budget measure. It is all about money; it is not about looking after people with disabilities. If the government can push 200,000 people off the disability support pension and onto the dole with a cut of some $\$ 60$ per fortnight, you 
can see that this would appear to be a substantial amount of money (Mr Mossfield in

Commonwealth of Australia. House of Representatives, 26 Mar 2003, p.13545).

The Welfare to Work Act was justified by the claim that "the best form of welfare is a job" (Andrews, Minister Assisting the Prime Minister for the Public Service, in Commonwealth of Australia. House of Representatives, 12 May 2005, p.88). Drawing on this mentality, the Government promoted its policies as allowing people with disabilities to participate in the “nation’s prosperity” (Commonwealth of Australia. House of Representatives, 9 Nov 2005, p.2), presenting the reform as an opportunity for people with disabilities to become effective members who actively contribute to the national economy, rather than as a restriction on disability welfare eligibility.

In transforming people with disabilities into active citizens, the Welfare to Work Act (2005) drew on the concept of productivity, prescribing that they must seek part-time paid employment if assessed as semi-productive, which means being able to work between 15 and 30 hours a week and undertake training activities (Welfare to Work Act 2005, Schedule 2, Part 1, Subsection 94 (5)). Every person with disabilities is required to respect these rules and principles, or lose access to financial assistance for a specific time (Employment and Workplace Relations Legislation Amendment (Welfare to Work and Other Measures) Act, 2005). Financial benefits are restored when the person with disabilities proves their compliance with the norms of an active individual. Thus, the Welfare to Work Act is a government mechanism to depict the expected behaviour of an active person and give recipients an opportunity to live in accordance with the foremost principle of a neoliberalist society: the obligation to engage in paid work. 


\section{Accounting for constructing an effective person with disabilities}

To completely transform people with disabilities into effective entities, an administrative system was organised. The first action of the administrative procedure is to identify eligible DSP recipients, so that appropriate procedures can be undertaken to transform them. Foucault (1988c) writes that in order to provide direction towards salvation, the pastor demands unconditional access to every aspect of the sinner through the means of confession. In a similar way, the in-depth knowledge required to transform people with disabilities is acquired through the filing of official forms, including the Claim Form and Income and Assets Form ${ }^{4}$ (Centrelink, 2006c). These forms are a means of written confession for individuals who want to be considered as DSP recipient, as they provide insights into aspects of individuals' lives, including demographic and financial information and intimate details of their lives, such as with whom they are sharing a bed and their living arrangements with that person (Centrelink, 2006a, B15, p.6).

Government guidelines for administering the Welfare to Work Act puts an emphasis on how to complete and lodge claims, stressing the critical importance of ongoing disclosure, or “confession” in Foucault’s (2007) terms (Australian Government, 2006b, 2006c). The claims for the DSP must be in writing, on an approved form, completed (preferably in ink), signed by the customer and, if relevant, their partner, and delivered to a place and/or a person approved by the secretary (Australian Government, 2006c). Claims must be lodged in Australia, and “[a]ll necessary questions on the claim form MUST be answered” (Australian Government, 2006c, emphasis in original). In the same way that Foucault (1988c) noted the centrality of

\footnotetext{
${ }^{4}$ These forms are the mandatory documents for claiming the DSP. The applicants can be requested to confess more details of their personal affairs to prove their eligibility (Centrelink, 2006c; Department of Human Services, 2016a).
} 
confession for achieving salvation, the Act guidelines stress the significance of individuals' written confession for the purpose of obtaining access to the DSP (Australian Government, 2006c).

The Claim Form and Income and Assets Form put particular attention on the financial means of those who are applying for the DSP, and of their partners. For instance, the Claim Form demands that DSP applicants disclose the cost of their accommodation, the amount of bond in case of renting and the frequency of payment, and details of previous employment, including wages or salary earned (Centrelink, 2006a, Question K12-K14). With the agenda of promoting employment as a sign of righteousness, the Claim Form requires that individuals detail their training and working experience, as well as their level of productivity, and demands that they specify the date by which they believe they can become in some way productive (Centrelink, 2006a, Question K1- K11).

The Income and Assets Form requires further detailed information on the financial circumstances of the applicants and their partners. The information required includes income from current employment, income streams, financial investments, shares and securities on listed and unlisted stock exchanges, income from overseas, cash on hand, cash at bank, money on loan, lump-sum payments, household contents, superannuation, bonds, life insurance policies, vehicles, real estate, and compensations (Centrelink, 2006c). In addition, applicants are requested to record the current amounts for income and assets, as well as their share and their partners’ share (Centrelink, 2006c). For instance, for the item “Money on loan”, they are requested to disclose the name of the borrower, date of borrowings, amount borrowed, percentage lent by the applicants, percentage lent by the partner, and current balance of the loan (Centrelink, 2006c). 
This type of accounting information not only enables the Australian government to know certain aspects about the lives of people with disabilities, but also provides a mechanism to assess their “confession”. People with disabilities must present documents, such as bank statements, so that the authenticity of their claims can be verified (Centrelink, 2006b). In addition, Centrelink demands that people with disabilities disclose their and their partners' tax details (Centrelink, 2006a, Part E). This information is verified and cross-checked through other agencies confirm that the person's confession is accurate (Newman, 7.30 Report, 8 Nov 2000).

In deciding on the eligibility of people with disabilities for the DPS, Centrelink applies a two-part complex calculative program: the Income and Assets Tests. Centrelink draws on the individual's confessions regarding their financial means, gathered by the administrative forms, and extracts relevant information that assists in identifying their income and assets. Income, according to the Australian government for the purpose of the DSP, is:

An amount you earn, derive or receive for your own use or benefit profits, the amount of earnings in excess of expenses, whether of a capital nature or not, and a periodic payment or benefit you receive as a gift or allowance.

It includes:

income from outside Australia, monies, legal tender or cash, valuable consideration, you receive goods, services or some other benefit in exchange for an item, action or promise (Australian Government \& Department of Human Services, 2016f).

Whilst this is a general definition of income, the Income Test program specifies the assessable income that affects decisions on the people with disabilities entitlements. This means that, in interpreting individuals' confession, Centrelink relies on the government's classification of income and assets ${ }^{5}$. For instance, the Income Test prescribes that "the lump sums that are unlikely to be repeated, can't be reasonably predicted, and is [sic] not money paid

\footnotetext{
${ }^{5}$ Appendices I and II present the government's classification of income and assets for the purpose of social security payments.
} 
for a service or profit” are exempted (Australian Government \& Department of Human Services, 2016g). However, the way people with disabilities spend an exempt lump sum will affect the classification of the funds. For example, according to the Income Test, if the person uses the lump sum to increase their financial assets, such as saving it in a bank, lending it, or investing it, it becomes a deemed ${ }^{6}$ income, and thus affects the person's entitlement to the DSP (Australian Government \& Department of Human Services, 2016g). The Income Test acts, therefore, as a mechanism that interferes with the lives of people with disabilities in a way that indirectly controls behaviour.

A similar procedure is undertaken to assess the assets of people with disabilities. Centrelink applies the Asset Test on the applicants' confessions (Australian Government \& Department of Human Services, 2016a). The value of the assets is calculated by deducting any debts against the assets from their market value (Australian Government \& Department of Human Services, 2016a). Centrelink applies each test individually, and the test with the lower rate is used to determine the applicant's eligibility for the DSP (Australian Government \& Department of Human Services, 2016a).

The information obtained from the forms not only facilitates decisions on the entitlements of people with disabilities, but also provides a basis to monitor the applicants' financial conduct. This occurs by the means of Account Statement, which contains all personal and financial information extracted from the individual's confessions (Australian Government \& Centrelink, 2008). It includes the individual’s rate of DSP payment, any Centrelink debt, and current income and assets, including savings-account details, real-estate details, and other

\footnotetext{
${ }^{6}$ Centrelink has instigated a calculative mechanism, “deeming”, as part of the Income Test to assess the amount of income from financial investment. Deeming assumes that financial investments earn a certain rate of income, regardless of the amount of income they actually earn. If the investments are earning more than the rates set by deeming, the extra income is not assessed. According to the deeming rule, the first \$49,200 of a single individual's financial investments is deemed to earn income at the annual rate of $1.75 \%$, and any amount over that is deemed to earn income at 3.25\% per annum (Australian Government \& Department of Human Services, 2016c).
} 
payments and entitlements. Drawing on continuous reviews and confessions, Centrelink updates the Account Statement and monitors any successive variations in the financial circumstances of people with disabilities (Australian Government \& Centrelink, 2008). Enforcing pastoral power through the pursuit of every individual's welfare and the reaffirmation of the neoliberal ideology requires the pastor to know the truth about people with disabilities. The accounting information gathered by the administrative forms and stored in the Account Statements provides an in-depth knowledge of every person with disabilities and enables an individualised summary that is used to reinforce the intentions of a neoliberalist society.

Our analysis reveals that measuring individuals' productivity is critical in constructing the active citizen. In line with the Howard government's tendency to privatise public services (Mendes, 2008), a private assessment organisation performs the Job Capacity Assessment (Australian Government, 2006a): an assessor interviews applicants to measure and report on their productivity over a five-year period, and to articulate methods and procedures to improve their productivity (Australian Government, 2006a, 2012). In particular, in measuring the individuals' productivity, the assessor is guided to disregard any life crises the individual experiences (Department of Human Services, 2013, p.7-8), instead drawing on their own expertise and the individuals' confession of their financial circumstances, employment history, previous access to employment services as well as medical records endorsed by treating doctors $^{7}$ (Australian Government, 2012). The assessor uses this knowledge to decide on individuals' productivity and the barriers that prohibit them from finding and securing employment. Techniques of measurement enable the assessor to determine the impacts of each barrier on the individual's current and future productivity, and guide the individual towards

\footnotetext{
${ }^{7}$ This policy was introduced in the 2009-2010 Budget under the Disability Support Pension- better and fairer assessment, and commenced from 1 January 2012 (see Commonwealth of Australia, 2009, p.228).
} 
becoming “active” and “effective” (Department of Human Services, 2013, p. 2). This occurs by connecting the individuals to suitable employment or services that can assist them in overcoming those barriers, ultimately enhancing their productivity (Department of Human Services, 2013). In this way, the in-depth knowledge of individuals' productivity permits an individualised intervention to transform the person into an efficient individual, as well as setting a basis to verify further improvement and/or disobeying the assessor's orders for improvement.

The Income and Asset Tests, together with assessors' reports on individuals’ productivity, assist in determining whether the individual can be identified as a disability welfare recipient. This identification is accompanied by rights and obligations. A common obligation is fulfilling participation requirements: mandatory activities for people with disabilities to demonstrate their compliance with the expectations of being an active citizen, and thus to secure ongoing eligibility for welfare benefits (Australian Government, 2011, 2014). For DSP recipients, the confession made as part of the Job Capacity Assessment is critical in negotiating their participation requirements, as it can vary with their assessed level of productivity. For instance, those whose productivity is assessed as more than 15 hours per week are required to actively participate in a Program of Support ${ }^{8}$ (Australian Government, 2011).

The confession processes (Foucault, 2007), which include completing different application forms and interviews with Centrelink officers, are followed by a detailed inspection of the financial conduct of the person with disabilities. Centrelink has instigated a monitoring mechanism that ensures individuals' compliance with the participation requirements, central to which is mandatory reporting. For instance, if the individual is required to undertake

\footnotetext{
${ }^{8}$ The Program of Support includes activities such as job searches, job preparation, education and training, work experience, employment, return to work, vocational or occupational rehabilitation, injury management, and activities designed to assist the person to prepare for, find, or maintain work (Australian Government, 2016).
} 
employment as part of their Program of Support, they are obliged to lodge a Reporting Statement every fortnight by 5:00 pm on their reporting day (Australian Government \& Department of Human Services, 2014b). This statement, also known as the Income Report, details the total number of hours of work done by the individual and their partner during the reporting period, and their gross income. To assure the accuracy of the statement, the individuals are issued an Earning Worksheet, which records the hours worked and the hourly pay rate, including variations such as overtime (Australian Government \& Department of Human Services, 2014a). The individuals are requested to lodge the statement even if they have received no income during that period. The income report is the basis for Centrelink to calculate payments to the individuals and is used to monitor the transformation of people with disabilities.

Foucault (2007) argues that the relationship between pastors and individuals requires that individuals surrender themselves to their pastor for both spiritual matters and everyday life. The data obtained from the Department of Human Services indicates that reporting techniques enable Centrelink to know most aspects of the lives of people with disabilities. For example, DSP recipients are mandated to report changes in their circumstances, including changes to bank details, work status, income for both the recipient and their partner, accommodation details, the acceptance of a lump-sum payments, changes to residential addresses, and relationship status (Australian Government \& Department of Human Services, 2016b). It is through such intense investigation of individuals' financial conduct that compliance with the new "regime of truth" ${ }^{9}$ is assured.

\footnotetext{
${ }^{9}$ Foucault states that "each society has its regime of truth, its 'general politics' of truth: that is, the types of discourse which it accepts and makes function as true; the mechanisms and instances which enable one to distinguish true and false statements, the means by which each is sanctioned; the techniques and procedures accorded value in the acquisition of truth; the status of those who are charged with saying what counts as true" (Foucault, 1980, p.131).
} 
In addition, Centrelink might approach employers and oblige them to verify the employment status of the individual by completing the Employment Verification Report (Australian Government \& Department of Human Services, 2016d). This report details the employee's leave, dates they have been paid, the amount paid, the period covered by the pay, and any compensations claimed by the individuals, if applicable (Australian Government \& Department of Human Services, 2016e). If the individual's Program of Support requires them to actively seek a job and be willing to accept any suitable job, they might be issued with an Employer Contact Certificate. This report requires an employer who has been approached by a job seeker for an advertised or available job to verify that the individual has made a genuine effort to find work (Australian Government \& Department of Human Services, 2016d). Centrelink's relationship with third parties facilitates positioning the individual into a neverending network of observation. Such examinations assist in constituting a subject whose merits are analytically identified. The reports on DSP recipients’ attempts to fulfil their obligations and to improve their productivity are crucial for understanding their accounts and deciding on procedures to modify their status.

The significance of accounting to the reconfiguration of the disability welfare program is clear: the administrative procedure is concerned with the amount and nature of the income and assets of the person with disabilities. Similar to Foucault's (2007) description of pastoral power, which relies on ongoing observation of everyday conduct of individuals, people with disabilities are required to report changes in their finances, and the administrative procedure is designed to monitor DSP recipients' financial conduct. Analysing the finances and productivity of people with disabilities is fundamental for extracting truth and transforming identity. Accounting serves the purpose of reinforcing pastoral power through enabling the mechanisms by which power is exercised. 
The teaching of the "new truth" imposed by disability welfare reform is fundamental in implementing the neoliberal agenda of constructing active and responsible citizens. Consistent with the Christian pastorate's teaching regarding truth, central to the new regime of truth is its extraction from persons with disabilities. Confessing (Foucault, 2007) to financial circumstances, via the completion of numerous bureaucratic forms, allows assessors to obtain in-depth knowledge of the person. Foucault (2007) reveals that confession enabled the Christian pastor to formulate individualised care. In a similar way, confession regarding the level of productivity enables tailoring an individualised form of teaching, the purpose of which is to overcome the barriers that prohibit DSP recipients from being independent, and to turn them into effective individuals. Whilst people with disabilities may attempt to hide some aspect of their financial circumstances from the authorities to remain eligible for welfare benefits, accounting techniques, such as tracing, cross-checking and verification, permit officers to authenticate their declarations.

Accounting information, as well as information recorded in the supplementary documents that are presented to officers as evidence, functions as the mechanism of confession, enabling the bureaucratic system to extract truthful accounts. Income and assets forms and interviews with officers are integral in assessing individuals' conduct and identifying methods to improve their circumstances, inducing them to become self-dependent and effective. Regular interviews and reviews, in which the main concern is tracing modifications in DSP recipients' productivity and improving their finances, encourage them to follow the teaching of the new regime of truth. In this way, accounting enables pastoral power to be exercised over the lives of people with disabilities as they are transformed into effective entities. Hence the achievement of the promised disability welfare reform for people with disabilities is obtained by intervention in their financial conduct, with the intention of transferring them from welfare to the workforce. 
Remarkably, the Department of Human Services’ annual report announces the success of its administrative procedures insofar as it was able to transform the identity of people with disabilities via its access to their financial information. From 2005, the Department of Human Services' reports include information on the referrals of people with disabilities to a return to work program. The annual report highlights that, in line with the agenda of Welfare to Work Act, from December 2004 to June 2005, the voluntary referrals to the program "increased by 150 per cent, from about 4,000 to just over 10,000 per month” (Department of Human Services, 2005, p.12). However, while the Welfare to Work Act did lead people with disabilities into the workforce, it did not significantly change the volume of DSP recipients. Instead, the dramatic decrease in the number of DSP recipients and DSP expenditure was driven by the modification of the measurement techniques in 2012 (Parliament of Australia, 2018). The modification of the assessment regime, which relied on measuring the applicants' productivity, prioritising their financial circumstances and their ability to perform certain activities, over medical conditions, resulted in a significant decrease in the granting of the DSP to new applicants. As shown in Figure 1, the entry grant, or approval, rate decreased from “63\% between 2001-2002 and 2010-2011 to 43\% from 2011-2012 to 2014-2015” (Parliament of Australia, 2018, p.15) (see figure 1).

\section{Conclusion}

This paper has illustrated the crucial role of accounting in the context of disability welfare reform in Australia. The reform, which commenced in 2005 under the Howard government, continues to affect the provisions of disability welfare in Australia, reflected a neoliberal agenda in which every citizen was considered responsible for contributing to the wealth of the nation. The reform relied upon the reconfiguration of a regime of truth to articulate the entitlements and responsibilities of the disabled population through a range of legalisation and administrative practices. Further, we have shown that the current disability welfare program in 
Australia, the NDIS, continues to propagate the Howard's government neoliberal assumptions of disability welfare, and that accounting remains a forceful mechanism in implementing those perspectives.

Drawing on Foucault's pastoral power, we have demonstrated that the extraction of truth from people with disabilities is a vital procedure in transforming identity and directing them towards the ends desired by the power holder. As shown in our analysis, accounting is a powerful mechanism by which people with disabilities are examined by means of the provision of personal financial information. Highly detailed bureaucratic forms and mandatory reports are an influential mechanism to know the truth about people with disabilities, permitting the government, via Centrelink, to govern the disabled population in a way consistent with the objectives of a neoliberal society. The regular, written confession of financial status, by means of application forms and numerous reports, gives visibility to the economic aspects of disability identity, with an emphasis on overcoming disability by engaging in paid employment. Evidence provided by the accounting procedures of recording and reporting enables Centrelink to assess the actions of people with disabilities.

The accounting information extracted from the confession not only enables financial assistance to be tailored to the most appropriate level, but it also enables the conduct of people with disabilities to be monitored and any variations in behaviour and needs to be identified. Regular monitoring of the financial conduct of people with disabilities compels compliance with the prescribed norms of the disability welfare reform, which is concerned with the contribution of people with disabilities to the national economy rather than their medical and social circumstances. Simultaneously, accounting procedures inserted in the disability welfare reform reinforce the status of Centrelink as the care provider, normalising expectations to comply with Centrelink's rules and procedures. In this way, accounting facilitates the control 
of individuals’ conduct without appearing to do so (Miller \& O'Leary, 1987; Miller \& Rose, 1990).

Our paper is situated within related accounting studies that explore the influence of accounting on the execution of political objectives and policies (e.g., Álvarez-Dardet, Baños, \& Carrasco, 2002; Baker, 2013; Baños et al., 2005; Neu, 2000b; Sargiacomo, 2009; Walker, 2004). Of particular interest is the dialectical tacking that takes place as discourses shift between state micro-power and state macro-power. Foucauldian accounting research (e.g., Fuinez, 2005; Madonna, Maran, \& Cestari, 2014; Miller \& O'Leary, 1987; Quattrone, 2004; Roberts, Sanderson, Barker, \& Hendry, 2006; Walker, 2010) has demonstrated that either micro- or macro-power in its modern form works through normalising behaviour, examination, and observation to manage individuals and whole populations, and that techniques of accounting have made it possible for modern power to govern “docile” citizens (Napier, 2006; Stewart, 1992). We extend the conceptualisation of accounting from a technology of power to a technique of the self. The evidence presented in this paper reveals the manner in which individuals confess to their financial circumstances to transform themselves and attain salvation in the form of disability welfare. However, this study shows that a neoliberal government relies on accounting information drawn from individuals' confessions to provide salvation in the form of directing them towards participation in the workforce. In this way, we advance Foucauldian accounting literature by highlighting a new perspective on the modern state: it does not ignore individuals; rather, it takes advantage of them to achieve its own desires in the guise of advancing an individual's welfare. By demonstrating the centrality of accounting in the interplay of salvation, law, and truth within disability welfare reform, we demonstrate that accounting forcefully implements an individualising and totalising form of power over the lives of people with disabilities, with the intention of reinforcing a specific form of political ideology. We hope thus to contribute to awareness that accounting is not a neutral technique; 
rather, it is a socially constructed practice and is intensely involved in constructing individuals’ identities, in this case the identities of people with disabilities.

In analysing the role of accounting in the disability welfare reform introduced by the Howard Government, we drew on publically available archival material. By analysing archival data, we demonstrated the centrality of accounting in rationalising and implementing policies that aim to form the conduct of people with disabilities. Future work could extend our approach by undertaking empirical methods such as interviews to comprehend the experience of people with disabilities as the result of the importance given to the notion of mutual obligation in the accountability reform. In addition, further research is required to expose the role of accounting in the policies targeted at people with disabilities, particularly with respect to the recent Australian initiative to provide choice and control for people with disabilities (Department of Human Services, 2016b).

\section{References}


Abramovitz, M. (2006). Welfare Reform in the United States: Gender, Race and Class Matter. Critical Social Policy, 26(2), 336-364.

http://doi.org/10.1177/0261018306062589.

Álvarez-Dardet, C., Baños, J., \& Carrasco, F. (2002). Accounting and Control in the Founding of the New Settlements of Sierra Morena and Andalucia, 1767-72. European Accounting Review, 11(2), 419-439.

http://doi.org/10.1080/09638180220145678.

Andrew, J. (2007). Prisons, the Profit Motive and Other Challenges to Accountability. Critical Perspectives on Accounting, 18( 8), 877-904. http://doi.org/10.1016/j.cpa.2006.08.003

Arrington, E., \& Upton, D. R. (2013). Three "-isations": Thinking with but Beyond the Sociological in Comprehending Accounting in a Global Context. International Journal of Critical Accounting, 5(4), 327-345. http://doi.org/10.1504/IJCA.2013.056652

Australian Government. Guide to Social Security Law: 1.1.J.10 Job Capacity Assessment (JCA). (2006a).

http://webarchive.nla.gov.au/gov/20060912051716/http://www.facsia.gov.au/guides_ acts/ssg/ssguide-1/ssguide-1.1/ssguide-1.1.j/ssguide-1.1.j.10.html Accessed 10 March 2015.

Australian Government. Guide to Social Security Law: 2 Claim Verification. (2006b). http://webarchive.nla.gov.au/gov/20060819195742/http:/www.facsia.gov.au/guides_ acts/ssg/ssguide-2.html Accessed 12 October 2016.

Australian Government. Guide to Social Security Law: 8.1.1.20 Claim Lodgement - General Provisions. (2006c).

http://webarchive.nla.gov.au/gov/20060920031035/http://www.facsia.gov.au/guides_ acts/ssg/ssguide-8/ssguide-8.1/ssguide-8.1.1/ssguide-8.1.1.20.html Accessed 12 October 2016.

Australian Government. Guide to Social Security Law: 3.6.1.12 Qualification for DSP - 15 Hour Rule. (2011).

http://webarchive.nla.gov.au/gov/20091018205019/http://www.facsia.gov.au/guides_ acts/ssg/ssguide-3/ssguide-3.6/ssguide-3.6.1/pc_13675.html Accessed 10 March 2015.

Australian Government. Guide to Social Security Law: 1.1.J.10 Job Capacity Assessment (JCA). (2012).

http://webarchive.nla.gov.au/gov/20120321192328/http://www.facsia.gov.au/Guides_ Acts/ssg/ssguide-1/ssguide-1.1/ssguide-1.1.j/ssguide-1.1.j.10.html Accessed 10 March 2015.

Australian Government. Guide to Social Security Law: 3.6.1.110 Participation Requirements for DSP Recipients. (2014).

http://webarchive.nla.gov.au/gov/20140801191720/http://guides.dss.gov.au/guidesocial-security-law/3/6/1/110 Accessed 10 March 2015. 
Australian Government. Guide to Social Security Law: 1.1.A.30 Active participation in a program of support (DSP). (2016). http://guides.dss.gov.au/guide-social-securitylaw/1/1/a/30 Accessed 12 October 2016.

Australian Government, \& Centrelink. Account Statement. (2008). http://webarchive.nla.gov.au/gov/20080723194546/http://www.centerlink.gov.au/inter net/internet.nsf/individuals/account_statement.htm Accessed 12 October 2016.

Australian Government, \& Department of Human Services. Earnings Worksheet. (2014a). http://www.humanservices.gov.au/customer/forms/su505 Accessed 12 October 2016.

Australian Government, \& Department of Human Services. Income Reporting. (2014b). http://webarchive.nla.gov.au/gov/20140801015331/http://www.humanservices.gov.au /customer/enablers/centrelink/income-reporting Accessed 10 March 2015.

Australian Government, \& Department of Human Services. Assets. (2016a). http://www.humanservices.gov.au/customer/enablers/assets Accessed 12 October 2016.

Australian Government, \& Department of Human Services. Change of Circumstances. (2016b). http://www.humanservices.gov.au/customer/enablers/change-circumstances Accessed 12 October 2016.

Australian Government, \& Department of Human Services. Deeming. (2016c). http://www.humanservices.gov.au/customer/enablers/deeming Accessed 12 October 2016.

Australian Government, \& Department of Human Services. Employment Status Verification. (2016d). http://www.humanservices.gov.au/business/services/centrelink/employmentstatus-verification Accessed 12 October 2016.

Australian Government, \& Department of Human Services. Employment Verification Reports. (2016e). http://www.humanservices.gov.au/business/enablers/employmentverification-reports Accessed 12 October 2016.

Australian Government, \& Department of Human Services. Income. (2016f). http://www.humanservices.gov.au/customer/enablers/income Accessed 12 October 2016.

Australian Government, \& Department of Human Services. Lump Sums While Receiving an Income Support Payment. (2016g). http://www.humanservices.gov.au/customer/enablers/lump-sums-while-receivingincome-support-payment Accessed 12 October 2016.

Baker, C. R. (2013). Administrative and Accounting Practices in the Byzantine Empire. Accounting History, 18(2), 211-227. http://doi.org/10.1177/1032373212471172.

Baños, J., Gutierrez-Hidalgo, F., Alvarez-Dardet, C., \& Carrasco, F. (2005). Govern(mentality) and Accounting: The Influence of Different Enlightenment Discourses in Two Spanish Cases (1761 - 1777). Abacus, 41(2), 181-210. http://doi.org/10.1111/j.1467-6281.2005.00175.x. 
Barnes, C., \& Mercer, G. (2005). Disability, Work and Welfare: Challenging the Social Exclusion of Disabled People. Work, Employment and Society, 19(3), 527-545. http://doi.org/10.1177/0950017005055669

Bigoni, M., \& Funnell, W. (2015). Ancestors of Governmentality: Accounting and Pastoral Power in the 15th Century. Critical Perspectives on Accounting, 27 (March), 160176. http://doi.org/10.1016/j.cpa.2014.05.001

Brohman, J. (1995). Economism and critical silences in development studies: a theoretical critique of neoliberalism. Third World Quarterly, 16(2), 297-318.

http://doi.org/10.1080/01436599550036149

Bujaki, M. L., Gaudet, S., \& Iuliano, R. M. (2017). Governmentality and identity construction through 50 years of personal income tax returns: The case of an immigrant couple in Canada. Critical Perspectives on Accounting, 46, 54-74. http://doi.org/10.1016/j.cpa.2017.02.005.

Burchell, S., Clubb, C., Hopwood, A., Hughes, J., \& Nahapiet, J. (1980). The roles of accounting in organizations and society. Accounting, Organizations and Society, 5(1), 5-27. http://doi.org/10.1016/0361-3682(80)90017-3.

Burchell, S., Clubb, C., \& Hopwood, A. G. (1985). Accounting in Its Social Context: Towards a History of Value Added in the United Kingdom. Accounting, Organizations and Society, 10(4), 381-413. http://doi.org/10.1016/03613682(85)90002-9.

Carmona, S., Ezzamel, M., \& Gutierrez, F. (2002). The Relationship between Accounting and Spatial Practices in the Factory. Accounting, Organizations and Society, 27(3), 239-274. http://doi.org/1010.1016/S0361-3682(01)00028-9.

Carmona, S., \& Gutiérrez, F. (2005). Outsourcing as Compassion? The Case of Cigarette Manufacturing by Poor Catholic Nuns (1817-1819). Critical Perspectives on Accounting, 16(7), 875-903. http://doi.org/10.1016/j.cpa.2004.02.003.

Carnegie, G. D. (2014). Historiography for Accounting: Methodological Contributions, Contributors and Thought Patterns from 1983 to 2012. Accounting, Auditing \& Accountability Journal, 27(4), 715-755. http://doi.org/10.1108/AAAJ-08-2013-1430.

Carnegie, G. D., \& Napier, C. J. (1996). Critical and Interpretive Histories: Insights into Accounting's Present and Future hrough Its Past. Accounting, Auditing \& Accountability Journal, 9(3), 7-39. http://doi.org/10.1108/09513579610121956

Centrelink. Claim for Payments for People with Disabilities, Illnesses or Injuries. (2006a). http://webarchive.nla.gov.au/gov/20060826000843/http://www.centrelink.gov.au/inter net/internet.nsf/forms/sa317_b.htm Accessed 12 October 2016.

Centrelink. How Do I claim Disability Support Pension? (2006b). http://webarchive.nla.gov.au/gov/20060820040327/http://www.centrelink.gov.au/inter net/internet.nsf/forms/claim_forms_dsp.htm Accessed 15 March 2015. 
Centrelink. Income and Assets Form. (2006c). http://webarchive.nla.gov.au/gov/20060826001507/http://www.centrelink.gov.au/inter net/internet.nsf/forms/sa369.htm Accessed 12 October 2016.

Chiapello, E., \& Baker, C. R. (2011). The Introduction of French Theory into English Language Accounting Research. Accounting, Auditing \& Accountability Journal, 24(2), 140-160. http://doi.org/10.1108/09513571111100663.

Commonwealth of Australia. (2009). Australian Government Budget Paper 2, 2009-2010. Canberra: Commonwealth of Australia Retrieved from http://archive.budget.gov.au/2009-10/index.htm

Commonwealth of Australia. House of Representatives. (1997). Parliamentary debates (Hansard). Retrieved from http://parlinfo.aph.gov.au/parlInfo/download/chamber/hansardr/1997-0210/toc_pdf/H\%201997-0210.pdf;fileType=application\%2Fpdf\#search=\%221990s\%201997\%2002\%2010\%20m r\%20howard\%22

Commonwealth of Australia. House of Representatives. (2003). Parliamentary debates (Hansard). Retrieved from http://parlinfo.aph.gov.au/parlInfo/download/chamber/hansardr/2003-0326/toc_pdf/2339-

2.pdf;fileType=application\%2Fpdf\#search=\%222000s\%202003\%2003\%2026\%20mo ssfield,\%20frank,\%20mp\%22

Commonwealth of Australia. House of Representatives. (2005). Parliamentary debates (Hansard). Retrieved from http://parlinfo.aph.gov.au/parlInfo/download/chamber/hansardr/2005-1109/toc_pdf/4353-

2.pdf;fileType=application\%2Fpdf\#search=\%222000s\%202005\%2011\%2009\%22

Cooper, C., Graham, C., \& Himick, D. (2016). Social Impact Bonds: The Securitization of the Homeless. Accounting, Organizations and Society, 55(November), 63-82. http://doi.org/10.1016/j.aos.2016.10.003.

Dean, M. (1999). Governmentality: Power and Rule in Modern Society. Thousand Oaks, Calif: Sage.

Department of Family and Community Services. (2000). Welfare Reform : A Stronger, Fairer Australia. Canberra: Dept. of Family and Community Services.

Department of Human Services.. Annual Report. Canberra: Australian Government (2005).

Department of Human Services. Guidelines for Job Capacity Assessments and Mandatory Requirements for Job Capacity Assessors. (2013). http://www.humanservices.gov.au/sites/default/files/documents/2013-01-10guidelines-and-mandatory-requirements-for-jca.pdf Accessed 12 October 2016.

Department of Human Services. Claiming Disability Support Pension. (2016a). http://www.humanservices.gov.au/customer/enablers/claiming-disability-supportpension Accessed 12 October 2016. 
Department of Human Services. People with disability. (2016b). http://www.ndis.gov.au/people-disability.html Accessed 10 Mar, 2015.

Department of the Parliamentary Library. (2005). Bills Digest No. 70 2005-2006 Employment and Workplace Relations Legislation Amendment (Welfare to Work and Other Measures) Bill 2005. Canberra: Department of the Parliamentary Library http://parlinfo.aph.gov.au/parlInfo/download/legislation/billsdgs/GB6I6/upload_binar y/gb6i66.pdf;fileType=application\%2Fpdf\#search=\%22r2461\%22.

Edgley, C. (2014). A genealogy of accounting materiality. Critical Perspectives on Accounting, 25(3), 255-271. http://doi.org/10.1016/j.cpa.2013.06.001

Employment and Workplace Relations Legislation Amendment (Welfare to Work and Other Measures) Act, 2005 (Cth).

Everett, J., Green, D., \& Neu, D. (2005). Independence, objectivity and the Canadian CA profession. Critical Perspectives on Accounting, 16(4), 415-440. http://doi.org/10.1016/j.cpa.2003.04.001

Fiske, L., \& Briskman, L. (2007). Rights and Responsibilities: Reclaiming Human Rights in Political Discourse. Just Policy, April(43), 50-54.

Fleischman, R. K., \& Tyson, T. (2003). Archival Research Methodology. In R. K. Fleischman, V. S. Radcliffe, \& P. A. Shoemaker (Eds.), Doing Accounting History (pp. 31-47). Oxford: Elsevier Science.

Foucault, M. (1980). Truth and Power. In C. Gordon (Ed.), Power-Knowledge: Selected Interviews and Other Writings, 1972-1977 (pp. 109-133). Hassocks: Harvester Press.

Foucault, M. (1982). The Subject and Power. In H. L. Dreyfus \& P. Rabinow (Eds.), Michel Foucault: Beyond Structuralism and Hermeneutics (pp. 208-226). New York: Harvester Wheatsheaf.

Foucault, M. (1988a). The History of Sexuality, Volume 1: An Introduction. New York: Vintage Books.

Foucault, M. (1988b). The History of Sexuality, Volume 2: The Use of Pleasure. New York: Vintage Books.

Foucault, M. (1988c). Technologies of the Self. In H. Gutman, P. H. Hutton, M. Foucault \& L. H. Martin (Eds.), Technologies of the Self: A Seminar with Michel Foucault (pp. 16-49). Amherst: University of Massachusetts Press.

Foucault, M. (1991). Governmentality. In G. Burchell, C. Gordon \& P. M. Miller (Eds.), The Foucault Effect: Studies in Governmentality: With Two Lectures by and an Interview with Michel Foucault (pp. 87-104). London: Harvester Wheatsheaf.

Foucault, M. (2000). Subjectivity and Truth. In P. Rabinow (Ed.), The Essential Works of Michel Foucault, 1954-1984, Ethics, Subjectivity and Truth (pp. 87-92). London: Penguin. 
Foucault, M. (2001). Omnes et Singulatim: Toward a Critique of Political Reason. In J. D. Faubion (Ed.), Power. Essential Works by Foucault, 1954-1984 Volume 3 (pp. 298325). New York: The New Press.

Foucault, M. (2003). Society must be defended : lectures at the Collège de France, 1975-76. In F. Ewald, A. Fontana, D. Macey \& M. Bertani (Eds.). New York Picador.

Foucault, M. (2007). Security, Territory, Population: Lectures at the Collège De France, 1977-1978. New York: Picador/Palgrave Macmillan.

Fuinez, D. R. (2005). The Interface of Disciplinary Practices and Accounting: The Case of the Royal Tobacco Factory of Seville, 1761-1790. Accounting History, 10(1), 71-97. http://doi.org/10.1177/103237320501000104.

Goodin, R. E. (2002). Structures of Mutual Obligation. Journal of Social Policy, 31(4), 579596. http://doi.org/10.1017/S004727940200675X.

Graham, C. (2010). Accounting and the Construction of the Retired Person. Accounting, Organizations and Society, 35(1), 23-46. http://doi.org/10.1016/j.aos.2009.03.001.

Greer, S., \& McNicholas, P. (2017). Accounting for "moral betterment”: Pastoral power and indentured Aboriginal apprenticeship programs in New South Wales. Accounting, Auditing \& Accountability Journal, 30(8), 1843-1866. http://doi.org/10.1108/AAAJ05-2013-1363.

Gustafsson, U., \& Driver, S. (2005). Parents, power and public participation: Sure Start, an experiment in New Labour governance. Social Policy \& Administration, 39(5), 528543. http://doi.org/10.1111/j.1467-9515.2005.00454.X

Haylett, C. (2003). Remaking Labour Imaginaries: Social Reproduction and the Internationalising Project of Welfare Reform. Political Geography, 22(7), 765-788. http://doi.org/10.1016/S0962-6298(03)00101-X.

Helsel, P. B. (2015). Pastoral Power Beyond Psychology's Marginalization: Resisting the Discourses of the Psy-Complex. New York: Palgrave Macmillan.

Himick, D. (2011). Relative performance evaluation and pension investment management: A challenge for ESG investing. Critical Perspectives on Accounting, 22(2), 158-171. http://doi.org/10.1016/j.cpa.2010.07.002

Hoskin, K. W., \& Macve, R. H. (1986). Accounting and the Examination: A Genealogy of Disciplinary Power. Accounting, Organizations and Society, 11(2), 105-136. http://doi.org/10.1016/0361-3682(86)90027-9.

Hoskin, K. W., \& Macve, R. H. (1988). The Genesis of Accountability: The West Point Connections. Accounting, Organizations and Society, 13(1), 37-73. http://doi.org/10.1016/0361-3682(88)90025-6.

Hoskin, K. W., \& Macve, R. H. (1994). Writing, Examining, Disciplining: The Genesis of Accounting's Modern Power. In A. G. Hopwood \& P. Miller (Eds.), Accounting as a Social and Institutional Practice (pp. 67-97). New York: Cambridge University Press. 
Humpage, L. (2007). Models of Disability, Work and Welfare in Australia. Social Policy and Administration, 41(3), 215-231. http://doi.org/10.1111/j.1467-9515.2007.00549.X

Ideland, M., \& Malmberg, C. (2015). Governing 'eco-certified children’ through pastoral power: critical perspectives on education for sustainable development. Environmental Education Research, 21(2), 173-182. http://doi.org/10.1080/13504622.2013.879696.

Jeacle, I. (2003). Accounting and the Construction of the Standard Body. Accounting, Organizations and Society, 28(4), 357-377. http://doi.org/10.1016/S03613682(02)00021-1.

Knights, D., \& Collinson, D. (1987). Disciplining the Shopfloor: A Comparison of the Disciplinary Effects of Managerial Psychology and Financial Accounting. Accounting, Organizations and Society, 12(5), 457-477. http://doi.org/10.1016/03613682(87)90031-6.

Kosmala, K., \& McKernan, J. F. (2011). From Care of the Self to Care for the Other: Neglected Aspects of Foucault's Late Work. Accounting, Auditing \& Accountability Journal, 24(3), 377-402. http://doi.org/10.1108/09513571111124054.

Loft, A. (1986). Towards a Critical Understanding of Accounting: The Case of Cost Accounting in the U.K., 1914-1925. Accounting, Organizations and Society, 11(2), 137-169. http://doi.org/10.1016/0361-3682(86)90028-0.

Loft, A. (1988). Understanding Accounting in Its Social and Historical Context: The Case of Cost Accounting in Britain 1914-1923. New York, NY and London: Garland Publishing.

Macintyre, C. (1999). From Entitlement To Obligation In The Australian Welfare State. Australian Journal of Social Issues, 34(2), 103-118. http://doi.org/10.1002/j.18394655.1999.tb01072.x

Macintosh, N. B. (2009). "Effective" Genealogical History: Possibilities for Critical Accounting History Research. The Accounting Historians Journal, 36(1), 1-27. http://doi.org/10.2308/0148-4184.36.1.1

Maddison, S., \& Martin, G. (2010). Introduction to 'Surviving Neoliberalism: The Persistence of Australian Social Movements'. Social Movement Studies, 9(2), 101120. http://doi.org/10.1080/14742831003603257.

Madonna, S., Maran, L., \& Cestari, G. (2014). The 1771 and 1824 Reforms of the University of Ferrara: A Foucauldian Analysis of Papal Interests. Accounting History, 19(4), 507-532. http://doi.org/10.1177/1032373214552317.

Malbon, E., Carey, G., \& Dickinson, H. (2018). Accountability in Public Service Quasimarkets: The Case of the Australian National Disability Insurance Scheme. Australian Journal of Public Administration, O(0). http://doi.org/10.1111/1467-8500.12246.

Martinez, D. E. (2011). Beyond disciplinary enclosures: Management control in the society of control. Critical Perspectives on Accounting, 22(2), 200-211.

http://doi.org/10.1016/j.cpa.2010.06.016 
McKinlay, A., Carter, C., Pezet, E., \& Clegg, S. (2010). Using Foucault to make strategy. Accounting, Auditing \& Accountability Journal, 23(8), 1012-1031. http://doi.org/10.1108/09513571011092538

McKinlay, A., \& Pezet, E. (2010). Accounting for Foucault. Critical Perspectives on Accounting, 21(6), 486-495. http://doi.org/10.1016/j.cpa.2009.08.006.

McKinlay, A., \& Taylor, P. (2014). Foucault, Governmentality, and Organization: Inside the Factory of the Future. London: Routledge.

Mendes, P. (2008). Australia's Welfare Wars Revisited: The Players, the Politics and the Ideologies. Sydney, N.S.W: University of New South Wales Press.

Miller, P., \& O'Leary, T. (1987). Accounting and the Construction of the Governable Person. Accounting, Organizations and Society, 12(3), 235-265. http://doi.org/10.1016/03613682(87)90039-0.

Miller, P., \& Rose, N. (1990). Governing Economic Life. Economy and Society, 19(1), 1-31. http://doi.org/10.1080/03085149000000001.

Napier, C. J. (2006). Accounts for Change: 30 Years of Historical Accounting Research. Accounting, Organizations and Society, 31(4-5), 445-507. http://doi:10.1016/j.aos.2005.12.004

Neu, D. (2000a). Accounting and Accountability Relations: Colonization, Genocide and Canada's First Nations. Accounting, Auditing \& Accountability Journal, 13(3), 268288. http://doi.org/10.1108/09513570010334126

Neu, D. (2000b). "Presents" for the "Indians": Land, Colonialism and Accounting in Canada. Accounting, Organizations and Society, 25(2), 163-184. http://doi.org/10.1016/S0361-3682(99)00030-6.

Neu, D., Everett, J., \& Rahaman, A. S. (2015). Preventing corruption within government procurement: Constructing the disciplined and ethical subject. Critical Perspectives on Accounting, 28, 49-61. http://doi.org/10.1016/j.cpa.2014.03.012.

Neu, D., \& Graham, C. (2006). The Birth of a Nation: Accounting and Canada’s First Nations, 1860-1900. Accounting, Organizations and Society, 31(1), 47-76. http://doi.org/10.1016/j.aos.2004.10.002.

Newman, J. (1999). The Future of Welfare in the 21st Century. Speech at the National Press Club. Canberra: Parliament of Australia. http://parlinfo.aph.gov.au/parlInfo/search/display/display.w3p;query=Id\%3A\%22med ia\%2Fpressrel\%2FNZF06\%22.

Parliament of Australia. (2018). Disability Support Pension Historical and projected trends Report no.01/2018. Canberra: Parliamentary Budget Office.

Peck, J. (2001). Neoliberalizing States: Thin Policies/Hard Outcomes. Progress in Human Geography, 25(3), 445-455. http://doi.org/10.1191/030913201680191772 
Quattrone, P. (2004). Accounting for God: Accounting and Accountability Practices in the Society of Jesus (Italy, Xvi-Xvii Centuries). Accounting, Organizations and Society, 29(7), 647-683. http://doi.org/10.1016/j.aos.2004.03.001

Radcliffe, V. S. (1998). Efficiency Audit: An Assembly of Rationalities and Programmes. Accounting, Organizations and Society, 23(4), 377-410. http://doi.org/10.1016/S0361-3682(97)00020-2.

Roberts, J., Sanderson, P., Barker, R., \& Hendry, J. (2006). In the Mirror of the Market: The Disciplinary Effects of Company/Fund Manager Meetings. Accounting, Organizations and Society, 31(3), 277-294. http://doi.org/10.1016/j.aos.2005.02.001.

Robson, K. (1992). Accounting Numbers as "Inscription": Action at a Distance and the Development of Accounting. Accounting, Organizations and Society, 17(7), 685-708. http://doi.org/10.1016/0361-3682(92)90019-O.

Sargiacomo, M. (2009). Accounting for the "Good Administration of Justice": The Farnese State of Abruzzo in the Sixteenth Century. Accounting History, 14(3), 235-267. http://doi.org/10.1177/1032373209335290

Soldatic, K. (2009). Disability and the Australian Neoliberal Workfare State (1996-2005). (PhD Thesis), The University of Western Australia.

Stewart, R. E. (1992). Pluralizing Our Past: Foucault in Accounting History. Accounting, Auditing \& Accountability Journal, 5(2), 57-73. http://doi.org/10.1108/09513579210011862

The Department of Families Housing Community Services and Indigenous Affairs. Gillard Government Delivers Disability Care Australia. (2013). http://jennymacklin.fahcsia.gov.au/node/2361 Accessed 13 Aug, 2013.

Thill, C. (2015). Listening for policy change: how the voices of disabled people shaped Australia’s National Disability Insurance Scheme. Disability \& Society, 30(1), 15-28. http://doi.org/10.1080/09687599.2014.987220.

Vollmer, H. (2003). Bookkeeping, Accounting, Calculative Practice: The Sociological Suspense of Calculation. Critical Perspectives on Accounting, 14(3), 353-381. http://doi.org/10.1006/cpac.2002.0528

Walker, S. P. (2004). Expense, Social and Moral Control. Accounting and the Administration of the Old Poor Law in England and Wales. Journal of Accounting and Public Policy, 23(2), 85-127. http://doi.org/10.1016/j.jaccpubpol.2004.02.001.

Walker, S. P. (2008). Accounting, Paper Shadows and the Stigmatised Poor. Accounting, Organizations and Society, 33(4/5), 453-487. http://doi.org/10.1016/j.aos.2007.02.006.

Walker, S. P. (2010). Child Accounting and "the Handling of Human Souls". Accounting, Organizations and Society, 35(6), 628-657. http://doi.org/10.1016/j.aos.2010.07.001. 
Walker, S. P., \& Carnegie, G. D. (2007). Budgetary Earmarking and the Control of the Extravagant Woman in Australia, 1850-1920. Critical Perspectives on Accounting, 18(2), 233-261. http://doi.org/10.1016/j.cpa.2005.10.003.

Watts, R., \& Zimmerman, J. (1986). Positive Accounting Theory. Englewood Cliffs: NJ: Prentice Hall.

Yayla, H. E. (2011). Operating Regimes of the Government: Accounting and Accountability Changes in the Sultan Süleyman Waqf of the Ottoman Empire (the 1826 Experience). Accounting History, 16(1), 5-34. http://doi.org/10.1177/1032373210389320

Zhang, Y., Andrew, J., \& Rudkin, K. (2012). Accounting as an instrument of neoliberalisation? Exploring the adoption of fair value accounting in China. Accounting, Auditing \& Accountability Journal, 25(8), 1266-1289. http://doi.org/10.1108/09513571211275470 
Figure 1: DSP Grant Rate (Percentage of applicants granted the DSP)

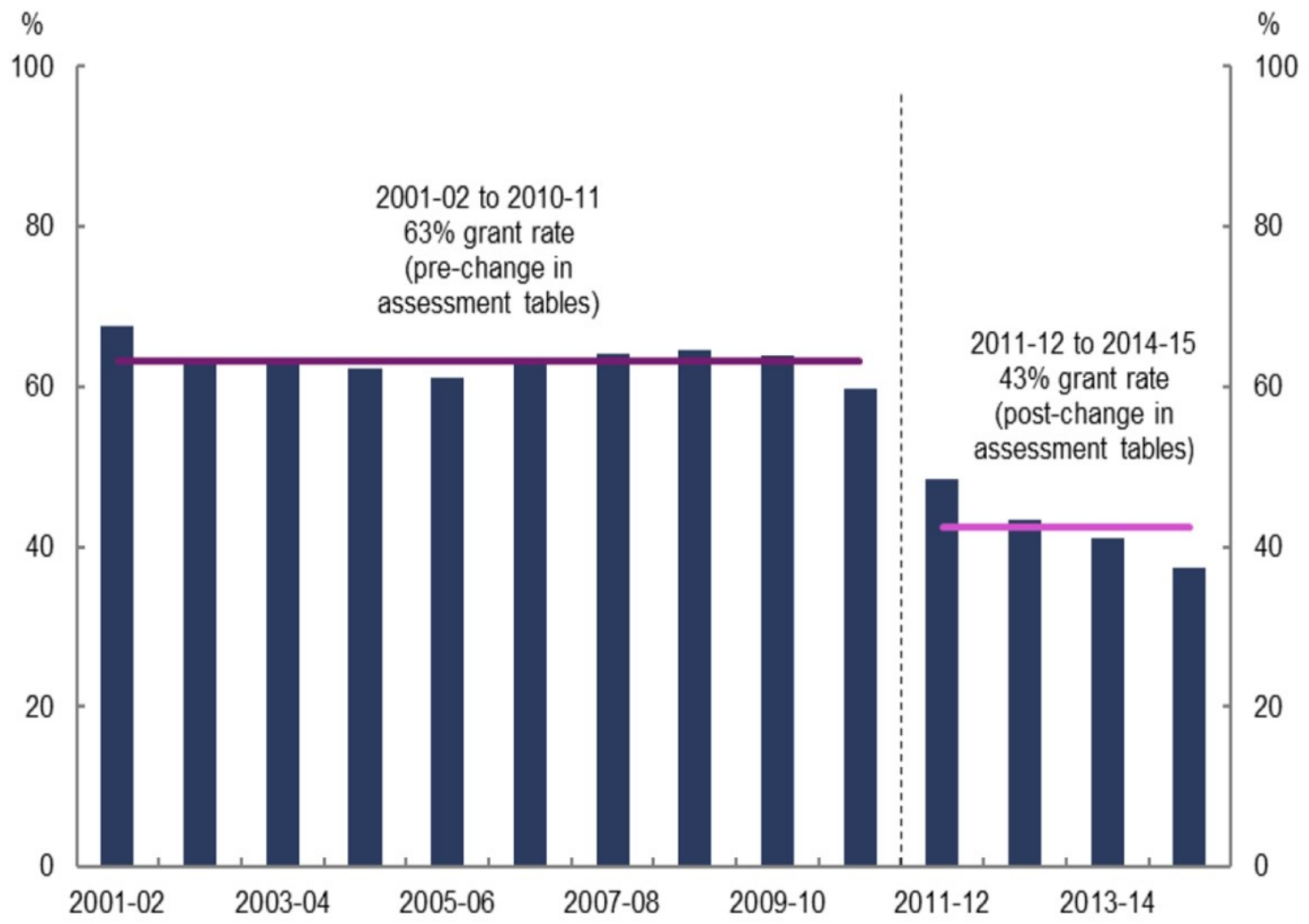

Source: Parliament of Australia, (2018, p. 15). 


\begin{tabular}{|c|c|}
\hline Examples of assessable income & Examples of exempt income \\
\hline $\begin{array}{l}\text { Deemed income from financial investments, } \\
\text { including money in superannuation funds if you } \\
\text { have reached age pension age. }\end{array}$ & Rent assistance from government. \\
\hline $\begin{array}{l}\text { Gross employment income - this is anything you } \\
\text { earn from work, as well as your wages it } \\
\text { includes: bonuses: penalty rates and overtime, } \\
\text { commissions, fringe benefits, and amounts you } \\
\text { salary sacrifice into super. }\end{array}$ & Most payments from Centrelink. \\
\hline $\begin{array}{l}\text { Income from a sole trader or partnership } \\
\text { business. }\end{array}$ & $\begin{array}{l}\text { Compensation for loss or damage to things the } \\
\text { applicant owns. }\end{array}$ \\
\hline Income from a farm. & Child support. \\
\hline $\begin{array}{l}\text { Distributions or dividends from a private trust or } \\
\text { private company. }\end{array}$ & Regular payments from a close relative. \\
\hline $\begin{array}{l}\text { Real estate income, including income from rental } \\
\text { property and from boarders and lodgers. }\end{array}$ & Any free board and lodging the applicant gets. \\
\hline Reportable superannuation contributions. & Emergency relief or similar assistance. \\
\hline Some lump sums. & Some lump sums. \\
\hline $\begin{array}{l}\text { Some types of income specific to Indigenous } \\
\text { Australians. }\end{array}$ & $\begin{array}{l}\text { First Home Saver Account withdrawals or } \\
\text { interest. }\end{array}$ \\
\hline \multirow[t]{4}{*}{ Paid Parental Leave payments. } & Repayment for expenses. \\
\hline & $\begin{array}{l}\text { Some allowances if the applicant spends the } \\
\text { whole amount on what it's meant for; for } \\
\text { example, work travel. }\end{array}$ \\
\hline & $\begin{array}{lll}\text { Payments through a } & \text { National } & \text { Disability } \\
\text { Insurance Scheme package. } & \end{array}$ \\
\hline & $\begin{array}{l}\text { Payments as a victim of National Socialist } \\
\text { persecution. }\end{array}$ \\
\hline
\end{tabular}




\begin{tabular}{|c|c|}
\hline Asset Type & Measurement \\
\hline Real estate & $\begin{array}{l}\text { Include the value of real estate that's not applicant's principal home. Real estate assets } \\
\text { can include property owned: } \\
\text {-in full or jointly } \\
\text {-privately or within a business structure. }\end{array}$ \\
\hline Granny flat rules & $\begin{array}{l}\text { If the applicant transfers assets or money to live in a property that someone else owns, the } \\
\text { case might be assessed under the granny flat rules. }\end{array}$ \\
\hline $\begin{array}{l}\text { Retirement village } \\
\text { contributions }\end{array}$ & $\begin{array}{l}\text { The amount of entry contribution paid to live in a retirement village affects if: } \\
\text { - the applicant is classed as a home owner, and } \\
\text { - this will be included in the assets test. }\end{array}$ \\
\hline Life interests & $\begin{array}{l}\text { Centrelink may assess an asset if the applicant: } \\
\text { - have a life interest in the asset, or } \\
\text { - get a lifetime income from the asset. }\end{array}$ \\
\hline Financial investments & $\begin{array}{l}\text { Centrelink will use the value of applicant's financial investments to calculate the payment } \\
\text { rate. Centrelink assesses the financial investments under both the assets and income } \\
\text { tests. }\end{array}$ \\
\hline Business assets & $\begin{array}{l}\text { If the applicant is involved in a business as a partner or sole trader, Centrelink will decide } \\
\text { income and assets relate to the applicant. } \\
\text { If Centrelink decides the applicant is a controller of a private trust or private company, it } \\
\text { will assess its income and assets. In this case, Centrelink will not assess the capital } \\
\text { injection made into a private trust or private company. }\end{array}$ \\
\hline Income streams & $\begin{array}{l}\text { An income stream is a regular series of payments: } \\
\text { - } \quad \text { made directly from accumulated superannuation contributions, or } \\
\text { - } \quad \text { purchased using superannuation or other money. }\end{array}$ \\
\hline Funeral investments & Some funeral investments may be either partially or fully exempt from the assets test. \\
\hline Assets given away & $\begin{array}{l}\text { The applicants or their partner can give away money, assets or income at any time. If it's } \\
\text { more than the allowable gifting amount, it'll affect the payment. }\end{array}$ \\
\hline Other assets & $\begin{array}{l}\text { Centrelink assesses the market value of: } \\
\text { - } \text { motor vehicles } \\
\text { - } \text { boats } \\
\text { - } \text { licences, such as fishing or taxi } \\
\text { - the surrender value of life insurance policies } \\
\text { - trading, hobby or investment collections } \\
\text { - cyber currency such as Bitcoins } \\
\text { - household contents, and } \\
\text { - personal items. }\end{array}$ \\
\hline
\end{tabular}




\begin{tabular}{|c|}
\hline Examples of Exempt Assets \\
\hline The principal home and up to 2 hectares of used land on the same title. \\
\hline Rural customers and primary producers with larger properties on the same title may be exempt in some cases. \\
\hline Some income streams depending on when they were purchased. \\
\hline Any property or money left to the applicants in an estate, which they can't get for up to 12 months. \\
\hline A cemetery plot and a prepaid funeral, or up to 2 funeral bonds, that cost no more than the allowable limit. \\
\hline Aids for people with disability. \\
\hline Money from the National Disability Insurance Scheme for people with disability. \\
\hline $\begin{array}{l}\text { Principal home sale proceeds that the applicants use to buy another home within } 12 \text { months - Centrelink } \\
\text { deems the exempted amount and include it in the income test. }\end{array}$ \\
\hline $\begin{array}{l}\text { Any interest not created by the applicants and their partner, including: } \\
\begin{array}{l}\text { - } \quad \text { life interest } \\
\text { - } \text { reversionary interest } \\
\text { - } \text { remainder interest, or } \\
\text { - contingent interest. }\end{array}\end{array}$ \\
\hline A Special Disability Trust if it meets certain requirements. \\
\hline The principal home, if the applicants vacate it for up to 12 months. \\
\hline Granny flat rights where the applicants pay more than the extra allowable amount. \\
\hline $\begin{array}{l}\text { Centrelink may not assess rural customers and primary producers with larger properties on the same title. } \\
\text { Centrelink also may not assess most compensation or insurance payments for loss or damage to buildings or } \\
\text { personal items. }\end{array}$ \\
\hline
\end{tabular}

Adapted from Australian Government and Department of Human Services (2016a) 